\title{
Digital Literacy: Text Credibility on Critical Reading Material
}

\author{
${ }^{1}$ Ayunita Leliana, ${ }^{2}$ Laily Maulida Septiana Harti*, ${ }^{3}$ Fauris Zuhri, and \\ ${ }^{4}$ Dwi Nur Cahyani Sri Kusumaningtyas \\ Universitas Negeri Surabaya) \\ *Corresponding Author \\ Email: lailyharti@unesa.ac.id
}

\begin{abstract}
With the onset of the digital era, the classroom's teaching and learning process has also shifted. The use of technology makes it easy for lecturers and students to access various information and references on the internet. However, not all of the information and concerns come from reliable and credible sources, so it is necessary to select and sort out the references used. This research's background determines students' ability to find and utilize and evaluate the credibility of information to be used in their writing. Although most students can use digital technology in their daily lives, they have difficulty determining whether the articles or texts from the internet come from credible sources or just subjective opinions that are not strong enough to be used as references in the 2018 class. Students skills have an impact on the search for reference sources when they write scientific papers. The preliminary observations on students of 2018 and 2019 have shown that some students stated that they were very familiar with information technology and accessed the internet skillfully. Some had difficulty finding the required references. The output of this research is a guide for checking the credibility of references and articles published in journals so that the public can refine the findings of this study by providing contributive input. If the results are positive, it means that they can be applied to other courses in other classes as well.
\end{abstract}

Keywords: digital literacy, critical reading, text credibility

\section{INTRODUCTION}

Initially, literacy was understood only as activities related to reading and writing. However, in recent years, literacy has been linked to the abilities in the realm of digital literacy as part of sustainable development (Annan, 2005; Bertschy, Künzli, \& Lehmann, 2013; E. Oghenekohwo \& A. Frank-Oputu, 2017; Wiek, Withycombe, \& Redman, 2011). Digital literacy includes the ability to understand the information contained in online media. Students in general are familiar with the technological access to online information. They find no difficulties in accessing almost every kind of data. However, in classroom setting, students still need to be directed to use this technology for academic and scientific purposes (Maharana \& Mishra, 2007). Lynch (2017) explains that digital literacy is about using technology and evaluating the information received. In a more detailed description, Steele (2009) defines digital literacy as the ability to search, evaluate, utilize, share and create content using information technology and the internet. In classroom setting, literacy concepts that appear in the teaching and learning process of reading course include understanding text in various forms (news articles, scientific articles, and videos), conveying information from the text that has been read, accessing links provided, and searching for the text from other sources. 
Pedagogical literacy changes gradually in the classroom in response to contemporary contexts of communication and learning. These changes are mixing as teachers and education researchers seek to devise new pedagogies to respond to digital technology's potential in existing curricula and assessment systems in the policy. Walsh (2010) explained that 16 teachers worked in nine elementary school classrooms to develop new ways of imparting technology for literacy learning. Data from nine case studies provide evidence that teachers can combine print-based literacy teaching with digital communication technology in various curriculum areas. This study confirms that literacy has a redefinition in the current curriculum context, especially given the emergence of an alumni curriculum in several countries. The curriculum has new descriptors for language and literacy criteria in the framework of multimodal literacy, that is the literacy needed in contemporary times to read, see, respond and produce multimodal and digital text. Through his research results, Walsh (2010) concluded that students have learning experiences using digital technology and materials. The teachers in the research team found that multimodal literacy has been able to improve student learning outcomes. Multimodal literacy facilitates students to listen more, convey their ideas, and write down writing thoughts to enhance their speaking and listening, reading, and writing skills (Walsh, 2010).

Digital competence and digital literacy are concepts that are gaining popularism in public discourse. However, how learners understand the idea and how it is defined is not clear. Research conducted by Spante, Hashemi, Lundin, and Algers (2018) presents a systematic review of the concept of digital literacy used in research in Higher Education. The aim is to build a reference understanding of digital literacy and digital competence strategies over time, disciplines, countries, methods, and analysis levels using three databases for the literature's systematic review: Web of Science, Scopus, and the Center for Educational Resources Information. They limit the search for titles, abstracts, and keywords in the database. Inclusion criteria are peer-reviewed publications written in English. Initially, 107 bulletins between 1997 and 2017 were found, with 28 addressing digital competencies and 79 digital literacy. Their results indicate that there are various definitions used in research in higher education. The results obtained include: i) conducting more research based on a critical perspective to avoid the use of fair concepts, ii) taking the definitions of these concepts seriously, iii) avoiding cross-reference mismatches, and finally, iv) engaging in critical investigations of the legitimacy of research policies in the research domain higher education (Spante et al., 2018).

With the onset of the digital era, the classroom's teaching and learning process has also shifted (Lathipatud Durriyah \& Zuhdi, 2018). The use of technology makes it easy for lecturers and students to access various information and references on the internet. However, not all of the information and concerns come from reliable and credible sources. Therefore, it is necessary to select and sort out the references used. The researchers want to bring about digital literacy in the Critical Reading course, focusing on student literacy skills. This include checking the credibility of various text forms. The researchers also include scientific articles, articles published in online mass media, video, and audio to hone students' multimodal and digital literacy competencies. Academically, students can use this skill to get credible references to write scientific works whose credibility can be justified. 
Furthermore, they will have the ability to filter information which in this digital era is very easy to be manipulated. By having the ability to filter a text's credibility, they can differentiate trusted sources from those untrusted.

The Reading course in English Literature Department, Universitas Negeri Surabaya is one of the skills courses in the Outcome Based Education curriculum. It has four levels namely Intensive Reading Skills, Active Reading, Critical Reading, and Reading for Research. Considered as a more advanced course, Critical Reading has a role in preparing students to master several reading strategies and write summaries as a manifestation of critical thinking while reading related texts. The Critical Reading course is designed to equip students to take Reading for Research courses with a more comprehensive reading range. Developing an output-based curriculum by applying literacy activities is a challenge for the lecturers and the students. Lecturers must prepare the teaching materials that focus on student-centered learning, in which students have to learn to be independent in understanding the materials. In the Critical Reading class in 2019 cohort, the teaching team faced obstacles with students' independence to search for online texts from trusted sources. Some students have been able to search for references online, but they do not know how to check the text credibility just yet. To support the digital literacy movement and improve students' critical reading skills, the researchers will introduce some stages to check the credibility of the essential reading material references.

\section{METHOD}

\section{Research Design}

This research applied qualitative design to achieve its purposes, i.e. to reveal the students' digital literacy and assist them to check the references' credibility. In addition, the result of this research would be applied only for its participants. As stated by Miles, Huberman, and Saldaña (2014) that in a qualitative research, the researcher seeks to collect data on local participants' views from the ground through a mechanism of intense attentiveness, empathetic comprehension, and suspending or bracketing preconceptions regarding the topics under consideration.

\section{Participants}

76 students of the English Literature study program were taken as the respondents of this qualitative research. They are cohort 2019 who programed Critical Reading course in their third semester. They consist of 19 male students and 57 female students. They were in 3 different parallel classes taught by 2 lecturers. Though there were 2 lecturers, yet they taught using the same course outline, materials, and assessments, hence the participants of this research experienced the same learning experiences as stated in the course syllabus. They attended the class once a week for 100 minutes. Moreover, since it was 2 credit class, they had 100 minutes for independent study. After the mid-term test, they spent this independent study mostly practicing checking the credibility of the texts used as their references.

\section{Instruments}

Miles, et. al. (2014) determine that the main instrument of the qualitative research is the researcher himself. However, the online questionnaire and class observation were structured and conducted to collect the data. The online questionnaire consisted 7 items relating to the internet usage to assist students in comprehending 
texts. This open questionnaire was accessed by the participants through this link http://unesa.me/CRquestionnaire. Meanwhile, the observation was conducted by using field note. This field note used to record the participants' activities when they applied the steps in checking the credibility of the texts they chose.

\section{Procedures}

Figure 1 displays the steps in conducting the research.

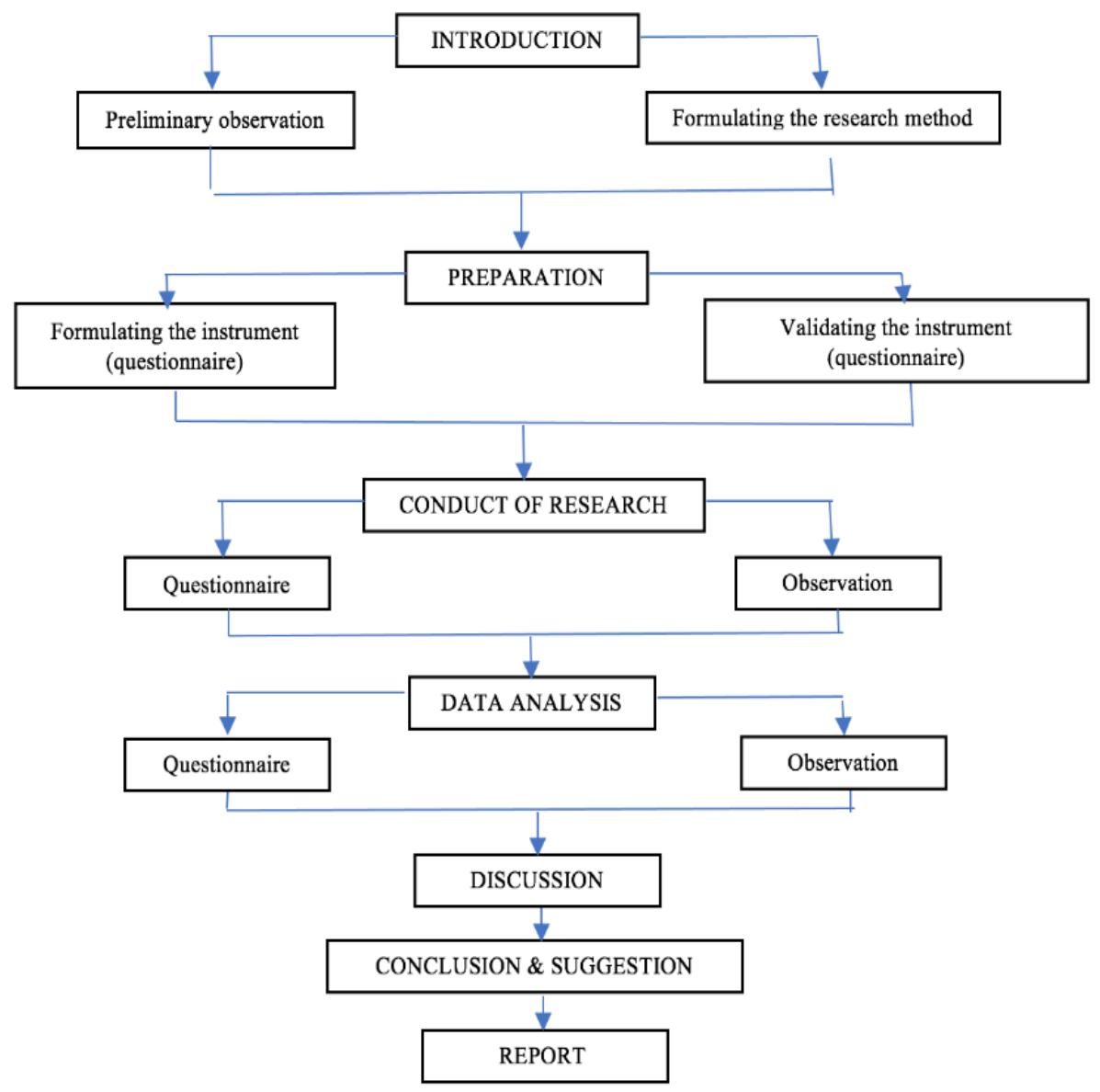

Figure 1. Research Procedures

\section{RESULTS AND DISCUSSION}

\section{Students' Digital Literacy: Accessing Text Online}

Digital literacy is a concept which states that all digital information available on the internet can be identified and used to form a complete understanding of related information. The use of the Internet makes it easy for lecturers and students to access various information and references on the internet. In relation to this, the students in the English Literature Department are familiar with the technological access to online information. They find no difficulties in accessing almost every kind of texts, as seen in Figure 2. 


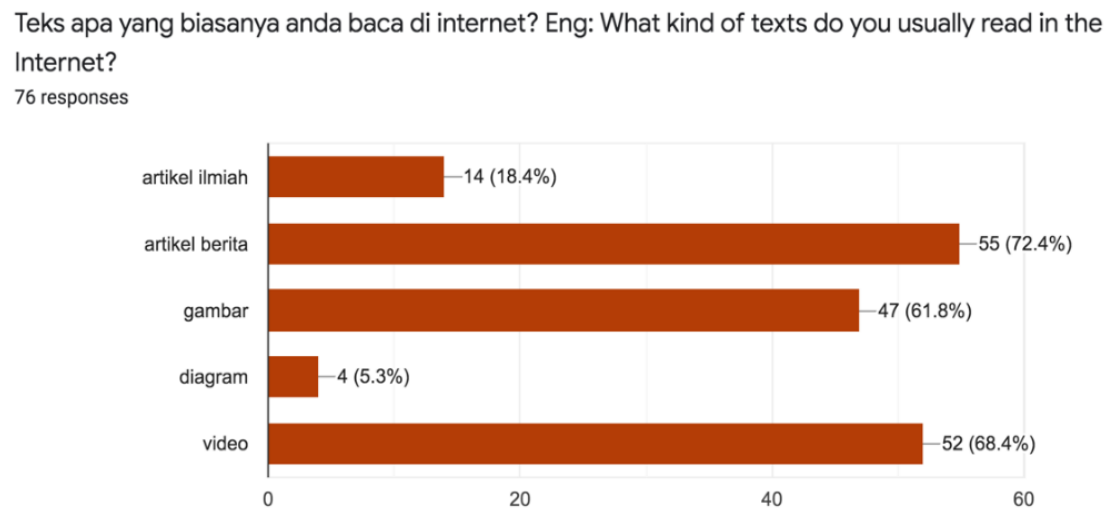

Figure 2. Kinds of Texts Students Read Online

From Figure 2, it is evident that the students can have access to different kind of text from the Internet. They make use of the Internet to mainly access news article, watch videos, and search for images, although unfortunately, scientific article posits low number with only 14 students $(18.4 \%)$ accessing it online. The main purpose of this research is to equip students with the ability to find reliable reading sources. Getting students used to literacy awareness is not something easy. In general, students have the ability to know the credibility of a text as seen in Figure 3.

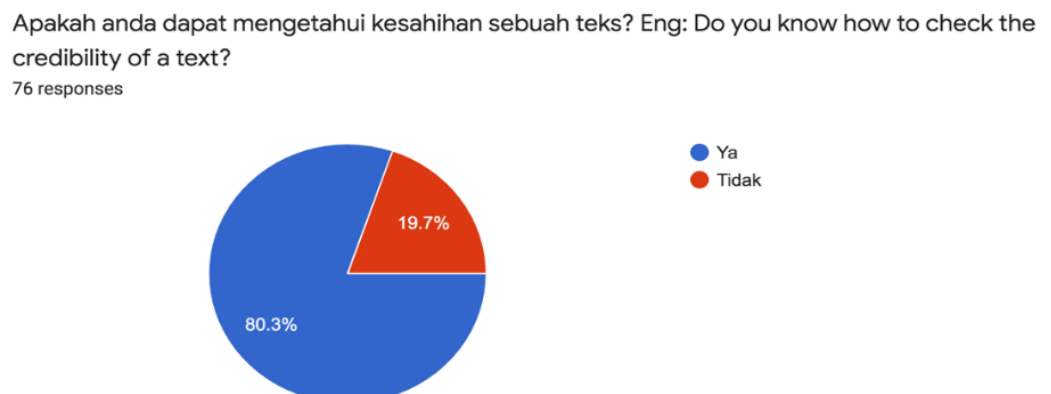

Figure 3. Students' Response to Checking Text's Credibility

The result of the questionnaire shows that 62 respondents know how to detect the credibility of the text they read. In addition, from the questionnaire distributed at the initial observation stage, it was found that some of the most common methods were used by students to determine the credibility of the text. The 3 most frequently used methods by students are 1) checking the domains of the online published article, 2) using SmallSeo Tools or CopyScape, and 3) opening other pages with the same news or information.

As the initial answer shows that students mentioned about checking other pages displaying the same news or information, the researchers assumed that the students already applied intertextuality. To further prove it, the researchers allow the students to access the Internet during their midterm exam (see Figure 4). From the responses, the students make use of the Internet to access online dictionary, to check other relevant links, and to find difficult or translate words (see Figure 5). 
Apakah pada saat UTS Critical Reading lalu anda menggunakan bantuan internet? Eng: Did you search the Internet during the Critical Reading midterm exam?

76 responses

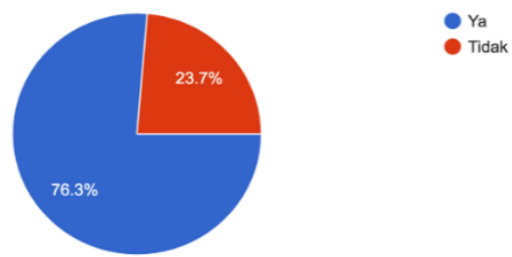

Figure 4. The number of students using the internet to assist them in answering questions on Critical Reading Midterm Exam

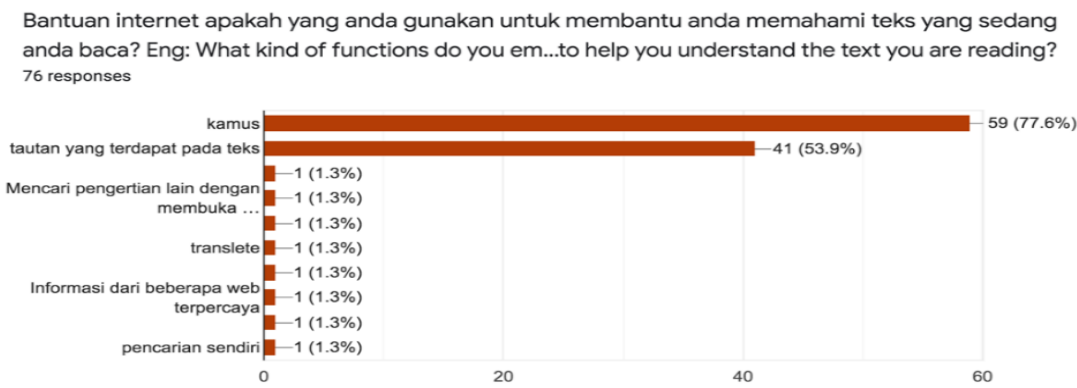

Figure 5. The Students' Use of the Internet

In the midterm exam for the Critical Reading course, a link was placed at the bottom of the image employed in the exam question sheet (Figure 6). This link provides an explanation of the pictures on the exam questions. This could affect the accuracy of student answers to the reading questions. By opening the available page, students will have complete information about the existing picture.

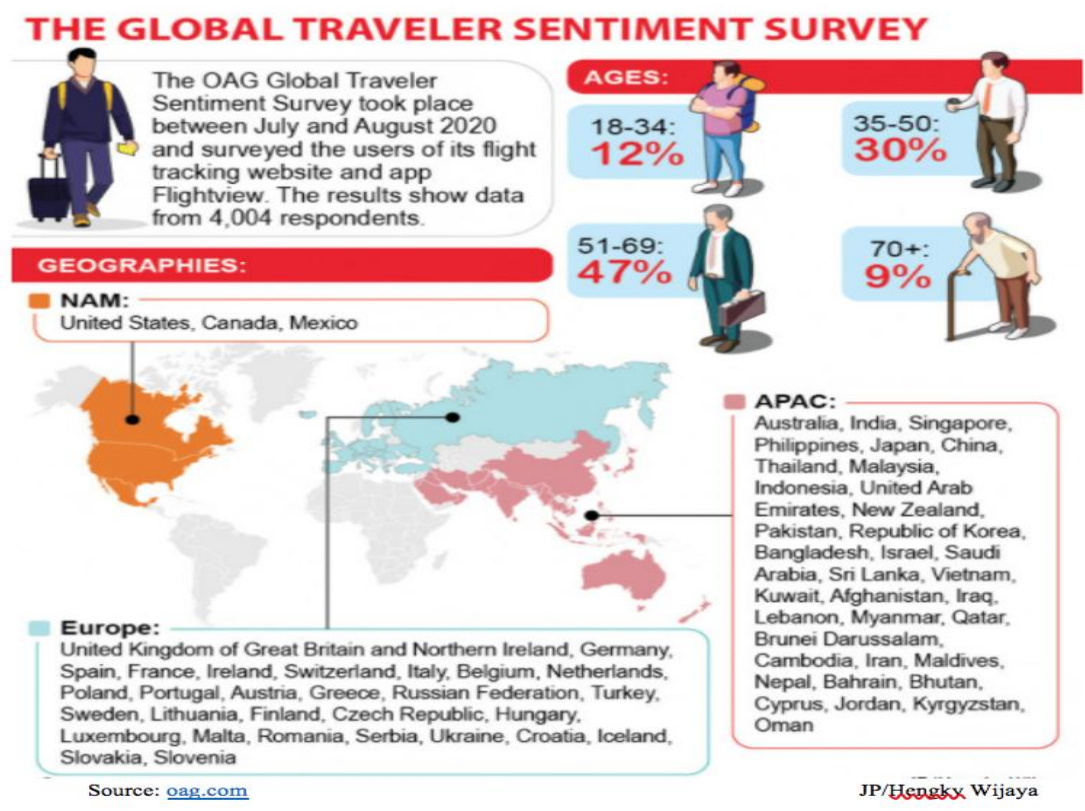

Figure 6. Image Employed in the Exam Question Sheet 
However, from the questionnaire, only 1 student accessed the link (Figure 7). This number shows the opposite condition recorded from the result of the questionnaire distributed at the initial observation stage. The majority of the students still use the basic functions of the internet to support their understanding of the course material such as to access English dictionaries to help them find out the definitions of some English words they do not know. They still believe that by knowing the meaning of a word, they can understand the text. They also do not know that there is information about the page that can be accessed in order to have a complete understanding of the information provided in the text. This results in the accuracy of their answers being classified as medium and low.

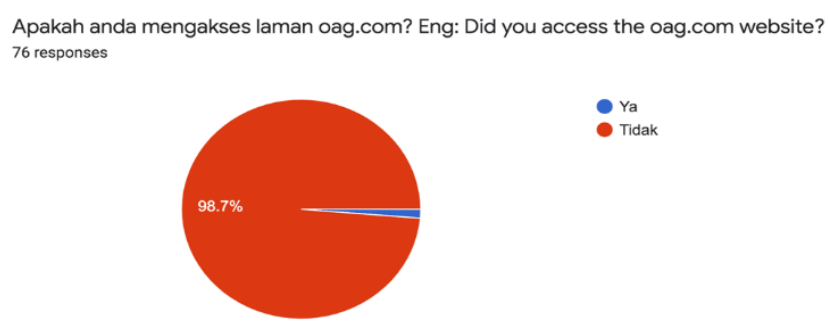

Figure 7. The number of students who access the pages available on the midterm exam questions for the Critical Reading course

Based on these observations, the researchers, which is also the teaching team for the Critical Reading course, think that they need to find the right way to hone students' digital literacy to a more advanced literacy level. To realize this plan, the research team formulated training to hone student digital literacy in the Critical Reading course. Finding from this training is described in the following discussion.

\section{Proposed Stages to Check Credibility of Texts}

Two lecturers in the Critical Reading course are members of the research team, so they are more flexible in providing training in checking the credibility of the text. The training in question is an activity to practice checking the credibility of the text which is carried out during lecture hours using the text credibility checking guide (see Appendix). Students are introduced to advanced steps apart from checking the domain of text to improve their digital literacy skills. These steps are:

1. Do not immediately believe that the author wrote valid information Students are asked to double-check with other sources. This step is done by going through additional online research or checking some print publications in the library. If the same information is found on several other legitimate websites as well as in print publications, it is likely that the information is accurate.

2. When given the text, students ensure that the organization that provided the text is trustworthy. Students check the domain of the page on which the text is uploaded if the text is shared online (government agencies or open contributors). 
3. Students also double-check the intertextuality contained in the text, including double-checking other pages or other text that is used as a reference. 4. When other semiotic resources are used, for example pictures, graphs, tables, diagrams, charts, students ensure that these semiotic sources are reliable and are based on actual data.

Furthermore, students are also introduced to the checking stage for several types of sources or text forms consisting of printed versions of text (for example reference books), text uploaded online, text in various forms (multimodal text), and articles in scientific journals. The steps in each type of text that are trained to students are: 1. A printed version of the text (for example a reference book)
a. Check author credentials
b. Check translator credentials
c. Checking publisher: who published the text
d. Check the year of publication
e. Check out the reference list

2. Text uploaded online

a. Checking site domains (.com, .edu, .org, .gov usually trusted)

b. Re-check information with other sources, for example local media, or other international media such as the New York Times, etc.

c. Checks the publication date of the text, including whether there is an inaccessible link on the URL

d. Check plagiarism to cited sources

3. Text with various shapes (multimodal text)

a. Check if the image is not recycled from an old source using the page https://www.duplichecker.com/reverse-image-search.php

b. Checking the source of graphs, tables, charts, graphs cited in text. This can be any link that follows the graph, table, chart, or chart itself.

c. Check the year of data collection.

4. Articles contained in scientific journals

a. Check journal publishers, access https://sinta.ristekbrin.go.id/journals for Indonesian journals or https://www.scimagojr.com/ for international journals to find out journal rankings.

b. Ensure that the journal is not published by a predatory journal.

c. Check the publication date. Research journals that are published for more than 5 years are considered not relevant journals anymore.

d. Check the reference list to make sure that it is not a plagiarism product, to ensure that the reference is valid and can be trusted.

\section{CONCLUSION}

The majority of English Literature Department students know how to access information online, however, their digital literacy in terms of checking the credibility of a text is still not optimal. Hence, the researchers consider the need to provide a customed guide to help the students when looking for credible references. The students can apply these skills in other courses. With a training on checking text credibility, their digital literacy skills are further enhanced. Students begin to get used to reading or identifying each feature in the text, like images or diagrams, 
and further readings or links listed at the bottom of the text or cited in the text. With this digital literacy sensitivity, students' critical reading skills are hoped to increase. Furthermore, they are ready to take Reading for Research course.

Based on the results of the research and the conclusions, the suggestions that the researchers propose are as follows (1) the study program can hold a training program on the importance of knowing the credibility of texts, especially those obtained from the Internet; and (2) lecturers as learning facilitators in class need to apply the guidelines that the researchers made in teaching and learning activities, so that students get used to checking the credibility of the text they employed.

\section{ACKNOWLEDGEMENTS}

This research has been funded by PNBP Universitas Negeri Surabaya. The scheme chosen was competitive research of the faculty policy 2020. It is a singleyear research. Research team consists of four lecturers of English Department of Universitas Negeri Surabaya and assisted by two students from the same department.

\section{REFERENCES}

Annan, K. (2005). Literacy and sustainable development. Bangkok: UNESCO. Bertschy, F., Künzli, C., \& Lehmann, M. (2013). Teachers' competencies for the implementation of educational offers in the field of education for sustainable development. Sustainability (Switzerland), 5(12), 5067-5080. https://doi.org/10.3390/su5125067

Lathipatud Durriyah, T., \& Zuhdi, M. (2018). Digital Literacy With EFL Student Teachers: Exploring Indonesian Student Teachers' Initial Perception About Integrating Digital Technologies Into a Teaching Unit. International Journal of Education and Literacy Studies, 6(3), 53-60. https://doi.org/10.7575/aiac.ijels.v.6n.3p.53

Maharana, B., \& Mishra, C. (2007). A survey of digital information literacy of faculty at Sambalpur University. Library Philosophy and Practice, 144, 1-9.

Miles, M. B., Huberman, A. M., \& Saldaña, J. (2014). Qualitative data analysis: A methods sourcebook. Thousand Oaks, California : SAGE Publications

Oghenekohwo, J., \& Frank-Oputu, E. (2017). Literacy Education and Sustainable Development in Developing Societies. International Journal of Education and Literacy Studies, 5(2), 126. https://doi.org/10.7575/aiac.ijels.v.5n.2p.126

Spante, M., Hashemi, S.S., Lundin, M., \& Algers, A. (2018). Digital competence and digital literacy in higher education research: Systematic review of concept use. Cogent Education.5(1), 1519143.

Steele, B. (2009). Digital literacy project teaches students the rules of the online academic world. Retrieved from Cornell Chronicle website: https://news.cornell.edu/stories/2009/12/project-teaches-rules-onlineacademic-world

Walsh, M. (2010). Multimodal literacy: What does it mean for classroom practice? Australian Journal of Language and Literacy. 33(3), 211-239.

Wiek, A., Withycombe, L., \& Redman, C. L. (2011). Key competencies in sustainability: A reference framework for academic program development. Sustainability Science, 6(2), 203-218. https://doi.org/10.1007/s11625-0110132-6 